\title{
THE CADETS FROM THE MILITARY SCHOOLS AS SUBJECTS OF EDUCATIONAL ACTIVITY
}

\author{
Venelin Terziev', Margarita Bogdanova ${ }^{2}$, Dimitar Kanev ${ }^{3}$, Marin Georgiev ${ }^{4}$ \\ ${ }^{1}$ Full Member of the Russian Academy of Natural History, Professor, Eng., D.Sc. (National \\ Security), D.Sc. (Economics), D.Sc. (Social Activities), Ph.D., Russian Academy of Natural History, \\ Moscow, Russia, Vasil Levski National Military University, Veliko Tarnovo, Bulgaria University of \\ Rousse, Rousse, Bulgaria, terziev@skmat.com \\ ${ }^{2}$ Professor, Ph.D., Tsenov Academy of Economics - Svishtov, Bulgaria, \\ m.bogdanova@uni-svishtov.bg \\ ${ }^{3}$ Professor, D.Sc. (Ec.), Ph.D.Nikola Vaptsarov Naval Academy, Varna, Bulgaria, \\ kanev@dkanev.com \\ ${ }^{4}$ Ph.D., National Military University, Veliko Tarnovo, Bulgaria, clementon@abv.bg
}

\begin{abstract}
Training is organized and systematically conducted process of active interaction, where the teacher's leading activity stimulates and directs the training activity and the trainees' behaviour with a view to achieving certain goals. It is bilateral process - of teaching and acquiring knowledge, establishing skills and turning them into habits

The goal of the present study is to reveal the essence of the reasons that lead to cadets' drop out of the AllArmy Faculty of National Military University and to propose actions for their impact reduction.
\end{abstract}

Keywords: drop-out, cadets, National Military University, education.

\section{INTRODUCTION}

Cadets in military universities are bearers of the typical for them general characteristics. They are adolescents on their way to maturity. Desires and aspirations develop earlier than will and strength of nature at this stage of their road of life. In such conditions, the adolescent is not always able to suppress some excessive and useless aspirations and desires. Adolescence is characterized by great optimism, belief in the own strength, sympathetic and good attitude towards people, sincerity, immediacy, sincere feeling for friendship. This function allows the future officers to form the noblest characteristics and to use their strength and energy for the big things the military profession requires. 


\section{PSYCHOLOGICAL CHARACTERISTICS OF CADETS FROM THE MILITARY SCHOOLS AS SUBJECTS OF EDUCATIONAL ACTIVITY}

The goal of the present study is to reveal the essence of the reasons that lead to cadets' drop out of the AllArmy Faculty of Vasil Levski National Military University and to propose actions for their impact reduction.

The reasons for discharging cadets are indicated in the Regulation for the Organization and Activity of Vasil Levski National Military University, published in State Gazette issue 83 of September 19th 2003, amended SG issue 56 of July 8th 2005, amended SG issue109 of December 23rd 2008.

Cadets are discharged from the university before the end of the term of education for the following reasons:

- for convicting of an intentional crime of general nature;

- for poor results;

- according to disciplinary order;

- at own free will;

- at occurring inability for military service, found by the competent healthcare bodies;

- at suspension of the allowance for access to classified information.

Here the cases, where single cadets are deprived of the physical ability to study in National Military University i.e. death, should also be added.

Cadets are discharged according disciplinary order when giving untrue data, on which grounds are accepted in the university and on systematic negligence of obligations on the curriculum or the university's regulations.

The obligations on the curriculum are considered systematically neglected when being absent more than 50 percent of the studying time of a semester, not certified semester or poor results. Semester is considered not certified when 3 or more studied subjects are not certified by the teachers because of unfulfilled study tasks. Obligations on the curriculum are considered unfulfilled because of poor results at three poor marks, given at regular semester exam session; two poor marks, given at correctional semester exam session; poor mark, given at liquidation exam session (Terziev, Nichev, 2017).

Systematic breaking the university regulations presents at the occurrence of three or more violations of obligations established with the university's regulations, committed by the trainees at the time of training.

According to the Law of Defence and Armed Forces (LDAF) of the Republic of Bulgaria, disciplinary punishment discharge, from the point of view of the fact that cadets are military men with special status, is obligatory imposed in the following cases:

- Conviction for intentional crime of general nature or deprivation of the right to occupy a state position or to exercise the profession or activity;

- Violation of the prohibitions to be members of political parties, movements and coalitions with political goals and to undertake actions within their service, with which they violate their political neutrality and to go on strike and to syndical activities;

- Failure to file a declaration according to the rules of LDAF;

- Systematic violation of rules for protection of the classified information, lead to unregulated access within the meaning of the Law for the Protection of the Classified Information;

- Failure to appear at work without reasonable causes in two working days in succession;

- Misuse of the official status;

- Destruction of property - state ownership, loss of materials, raw materials, energy and other means, when substantial damage has been caused to the state;

- Appearing of the military serviceman in a condition, which does not let him implement his official duties, because of using alcohol or misuse of narcotic substances;

- When because of guilty behaviour of the military serviceman there is a case of death or physical injury of his submitted military serviceman.

The analysis of the regulatory framework of the Republic of Bulgaria and of Vasil Levski National Military 
University shows that the cases of discharging cadets from the university before the end of the term of education listed above could be classified in the following groups:

- after disciplinary order, including at conviction for intentional crime of general nature and at deprivation of the allowance for access to classified information;

- because of poor results;

- after own free will;

- because of health reasons;

- because of death.

The social-psychological characteristics of cadets depend also on the nature and the contents of the educational and professional activity, the life experience, family status, upbringing, development, education and other factors. All this manifests in the spiritual appearance, the behaviour, demands and interests, in the daily activities of the future officers. Military university cadets have various needs in the complex interweaving, where sometimes the material ones are the leading, and sometimes the spiritual ones. The spiritual need first, the necessity of military profession excellent mastering, the conscientious attitude towards training, servicing and discipline is important for the future officers and has also leading role within their studying activities. Active process of forming view of life grounded on the cognitive needs, need of elaborating won attitude towards life is conducted during the cadet age. However, the ideological views and beliefs of the future officers are not sufficiently science-grounded and sometimes they are controversial. Cadets often have difficulties with the correct evaluation of social-political phenomena and events.

The cadets in the military universities are characterized with sharp sensitivity, strong impressionability, and increased emotionality. Each success provokes great delight, and a mistake or failure - deep concern and self-dissatisfaction. Future officers are very sensible towards defects and especially towards unjust attitude. This requires pedagogic tact and delicacy on the behalf of teachers and commanders.

One of the special cadets' characteristics is the clearly expressed straightforwardness of their decisions. Their statements are often unconditional, evaluations are categorical and hasty. Generally, cadets express their thoughts frankly. That should be considered in the training-educational work with the future officers, especially when it regards overcoming their wrong views. Tactically pointing the error is necessary, to rationally refute and to present the correct solutions. It is important for the commanders and the teachers in the military universities to have clear notion about the most general features of the moral and psychological image of cadets as well as about the characteristics of the future officers in the various courses.

The first course is the most complicated and difficult for the cadets. For many of them, the education in the military school is the beginning of independent life. The young men and women meet for the first time new atmosphere with unknown until them conditions of education and living in the military school.

There is a discrepancy arising between the primal forms of behaviour and the established requirements. Young cadets still haven't fully realized their nature and they haven't yet mastered the technique of execution. Severance with the former dynamic stereotype and forming new one and pre-structuring of the old and establishing new habits occurs. And this process is not painless. This can provoke negative psychic reactions and experience in the future officers.

A characteristic of the first course cadets is that there is discrepancy between volume, new things, complexity of studied material on one hand, and the lack of habits and skills for self-preparation in the circumstances of the military school - on the other. The cadets have didactic adaptation. They should be helped to learn to listen and write down lectures, to study individually and to summarize the recommended literature in order to be able to prepare quality for the seminar lessons.

The second course cadets have already experience in learning and servicing in the military school, they have acquired the necessary habits and skills for individual work on literature. The period for adapting to life and training activity in the university has actually finished. The cadets start acting more confidently, fulfilling the requirements of military oath and military statutes. The second course cadets have increasing interest towards studying social sciences.

The third course is already senior course. They have covered half of the way and have acquired rich experience of studying and servicing. The cadets are aware of the necessity to continue their education in the military university. There are huge positive changes in their spiritual appearance, in their views, attitude, and behaviour. The future officers already have more complete and filled with contents view, their ideological positions have strengthened, and they have formed a lot of professional habits and skills. Besides, the 
knowledge on many issues of social life has grown to beliefs and the capability of defending them by arguments appears.

The fourth course cadets are formed personalities in professional aspect. Their ideological views and beliefs get stronger, they have completed character, their skills are fully unfolded, and their life position is established. Their mental process has contents and operational aspect. The essential aspect of military thinking is defined by the specific of war as a social process, the circumstances and the nature of preparation for it, the goals of their practice activity in peace and war time. At the moment, military thinking is unity of political and military-technical contents.

Needs are the grounds of all cadets' motives. The need is momentum for the cadet. They require their satisfaction, provoke desires, aspirations, and emotional statuses and hence, make the trainees to be active, to put goals and to achieve them.

In order to achieve the present survey's goal, namely to uncover the essence and the reasons that lead to cadets' drop out of the All-Army Faculty, it is necessary to consider the opinion of the trainees, to outline the achievements and the disadvantages of the overall organization of life and education in the National Military University from their point of view.

Tracking the dynamics of development of the surveyed cadets' opinion is achieved through the adopted by the Vasil Levski National Military University Academic Board Methods for considering the trainees' opinion on the studying process and on the administrative service in Vasil Levski National Military University. It regulates the goal, subject, object, methods and organization of surveying and the way of reporting the trainees' opinion.

The method, through which the opinion of the Vasil Levski National Military University's trainees is studied, is a questionnaire card, specified for each group of studied people.

The criteria, after which the opinion is reported, are reduced to the attitude of the trainees towards the organization of the educational process, the way of teaching and the quality of living.

The attitude is measured through the extent of trainees' satisfaction, to which their needs and interests, arising in the National Military University social environment, are satisfied.

The indicators for measuring the extent of satisfaction of the educational process organization are: availability of internal regulatory documents, orders, instructions, the overall distribution of time in the National Military University, curricula, syllabuses, ensuring limit of time for preparation of university subjects (self-preparation), planning of educational process and transfer and accumulation of credits.

The indicators for measuring the extent of satisfaction of the way of education are: methods and forms of education, relevance of the taught material to the new things in the particular field, system for control and evaluation of knowledge, practical aspect of the taught knowledge, coverage with educational literature, leadership preparation.

The indicators for measuring the extent of satisfaction of the quality of living are: living conditions, internal order and organization, relationship with the teachers, relationship with the commanders and the managers, relationship with the colleagues.

A total number of 1561 cadets have been surveyed on the period 2008-2017. The results of the questioning are presented by year, where first and fifth course are separated for certain indicators because of the specifics of their answers (Terziev, Nichev, 2017; Terziev, 2017a; Terziev, Banabakova, Georgiev, 2017b).

The educational process's organization includes mainly the curricula and syllabuses, the planning of the educational process, the administrative service and the time distribution. If all this is fulfilled at high level, then this is precondition for the stronger motivation of cadets that leads to achieving higher results in education. Keeping the set in advance university subjects in the curriculum and the distribution of time helps educational process's optimization, the better distribution of mental and psychic strength, the solving of priority tasks and the opening of opportunities for full-value-recreation. The dynamics of dissatisfaction of the studied individuals from the All-Army Faculty under the criterion of "Organization of Educational Process" for the period 2008-2017 is presented at Figure 1. 


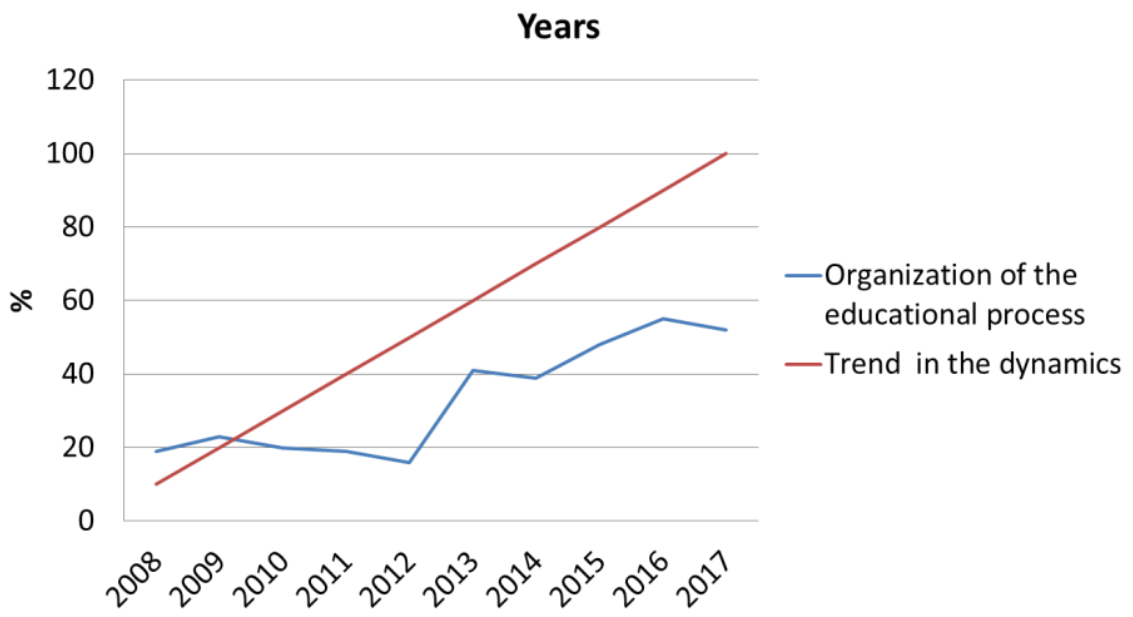

Figure 1. Dynamics in the dissatisfaction of the surveyed people in All-Army Faculty after the criterion "Organization of Educational Process" for the period 2008-2017.

The main trend in the dynamics after indicator "Organization of the Educational Process" of the cadets trained in the All-Army Faculty expresses in comparatively balanced dissatisfaction in the period 2008-2012 - from $16 \%$ to $23 \%$ and sharp rise of dissatisfaction in the sub-period $2012-2017$ - from $16 \%$ to $55 \%$. The results evidence that in 2016 and 2017 the dissatisfaction exceeds the satisfaction of cadets after the criterion "Organization of Educational Process" and this gives grounds for detailed analyzing of this period. Figure 2 illustrates the percentage rate of cadets' dissatisfaction after the criterion "Organization of Educational Process" and the relevant indicators.

\section{Indicators}

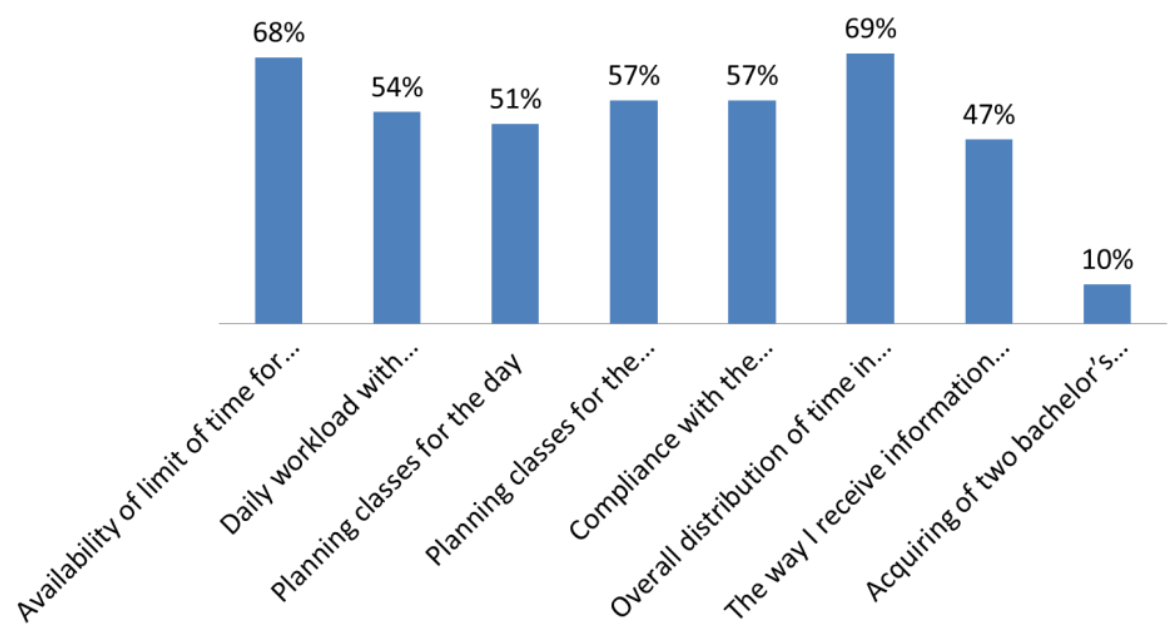

Figure 2. Percentage rate of cadets' dissatisfaction for the relevant indicators after the criterion "Organization of the Educational Process" for the period 2016-2017.

During the studied period, comparatively higher dissatisfaction after the indicator "Organization of the Educational Process" of the trainees in the All-Army Faculty is expressed mainly in the answers to questions regarding the overall distribution of time in the NMU and the availability of limit of time for preparation of the lessons (self-preparation), and the highest satisfaction (90\%) id from the acquiring of two bachelor's degrees. The satisfaction of the All-Army Faculty's trainees after the criterion „Organization of the Educational Process" and the indicators "overall distribution of time in Vasil Levski National Military University“ and „provision of limit of time for preparation of the lessons (self-preparation)“ for the period 20082017 is given in Table 1, and the dynamics of progress is given in Figure 3. 


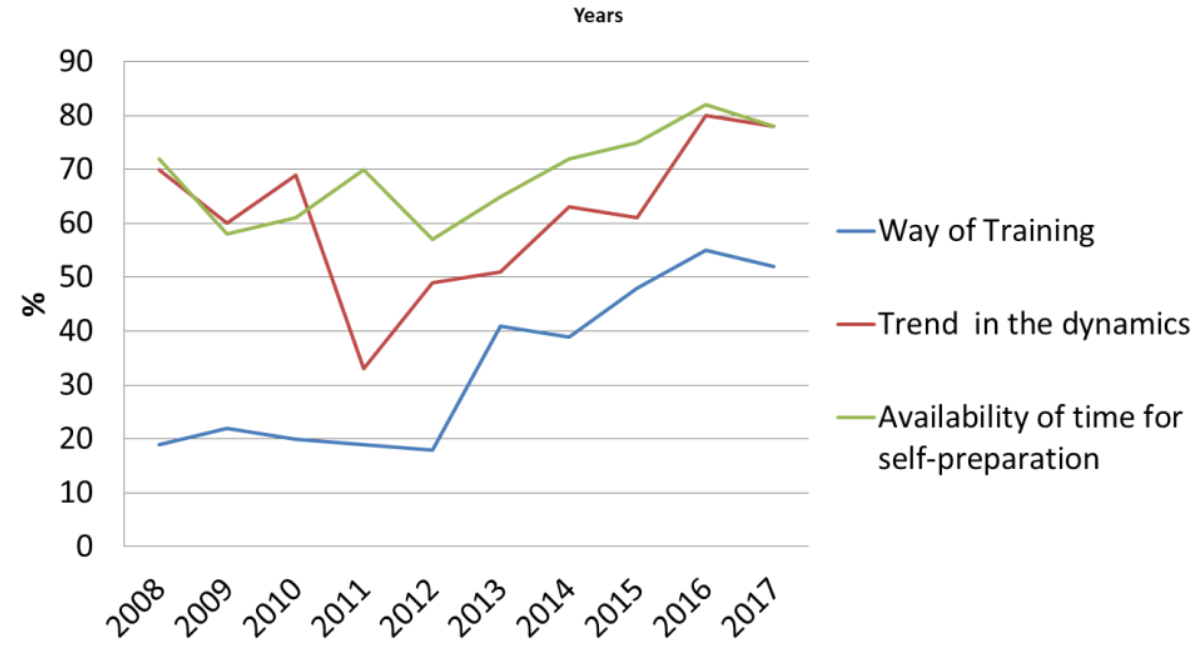

Figure 3. Dynamics in the extent of dissatisfaction of the trainees in the All-Army Faculty after the criterion "Organization of Educational Process" and the indicators "overall distribution of time in Vasil Levski National Military University" and "availability of limit of time for preparation of university subjects (self-preparation)" for the period 2008-2017.

Table 1. Extent of satisfaction after criterion "Organization of Educational Process" and the indicators "overall distribution of time in Vasil Levski National Military University"and "availability of limit of time for preparation of university subjects (self-preparation)"for the period 2008-2017

\begin{tabular}{|c|c|c|c|c|c|}
\hline \multirow[b]{2}{*}{ 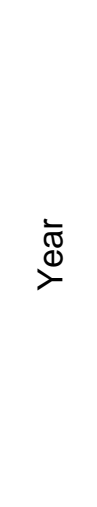 } & \multirow[b]{2}{*}{ 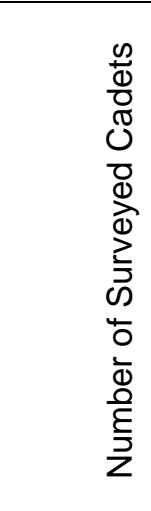 } & \multirow[b]{2}{*}{$\begin{array}{l}\text { Extent of } \\
\text { Satisfaction }\end{array}$} & \multirow[b]{2}{*}{ 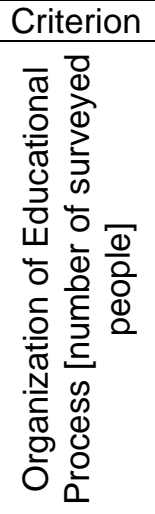 } & \multicolumn{2}{|c|}{ Indicators } \\
\hline & & & & 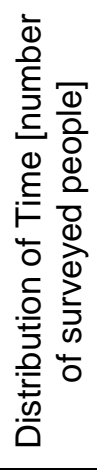 & 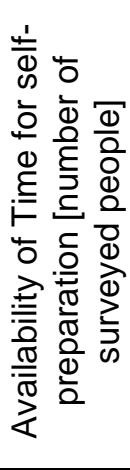 \\
\hline 2008 & 26 & $\begin{array}{l}\text { dissatisfied } \\
\text { satisfied }\end{array}$ & $\begin{array}{c}5 \\
21\end{array}$ & $\begin{array}{c}18 \\
8\end{array}$ & $\begin{array}{c}19 \\
7\end{array}$ \\
\hline 2009 & 93 & $\begin{array}{l}\text { dissatisfied } \\
\text { satisfied }\end{array}$ & $\begin{array}{l}21 \\
72\end{array}$ & $\begin{array}{l}56 \\
37\end{array}$ & $\begin{array}{l}52 \\
41\end{array}$ \\
\hline 2010 & 70 & $\begin{array}{l}\text { dissatisfied } \\
\text { satisfied }\end{array}$ & $\begin{array}{l}14 \\
56\end{array}$ & $\begin{array}{l}48 \\
22\end{array}$ & $\begin{array}{l}43 \\
27\end{array}$ \\
\hline 2011 & 176 & $\begin{array}{l}\text { dissatisfied } \\
\text { satisfied }\end{array}$ & $\begin{array}{c}34 \\
142\end{array}$ & $\begin{array}{l}62 \\
17\end{array}$ & $\begin{array}{c}122 \\
30\end{array}$ \\
\hline 2012 & 154 & $\begin{array}{l}\text { dissatisfied } \\
\text { satisfied }\end{array}$ & $\begin{array}{c}21 \\
133\end{array}$ & $\begin{array}{l}74 \\
80\end{array}$ & $\begin{array}{l}83 \\
47\end{array}$ \\
\hline 2013 & 158 & $\begin{array}{l}\text { dissatisfied } \\
\text { satisfied }\end{array}$ & $\begin{array}{c}49 \\
108\end{array}$ & $\begin{array}{l}82 \\
75\end{array}$ & $\begin{array}{c}103 \\
54\end{array}$ \\
\hline
\end{tabular}




\begin{tabular}{|c|c|c|c|c|c|}
\hline \multirow[b]{2}{*}{ 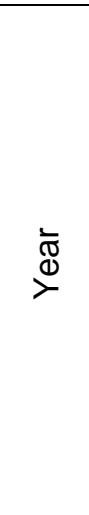 } & \multirow[b]{2}{*}{ 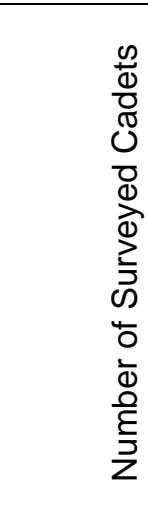 } & \multirow[b]{2}{*}{$\begin{array}{l}\text { Extent of } \\
\text { Satisfaction }\end{array}$} & \multirow[b]{2}{*}{ 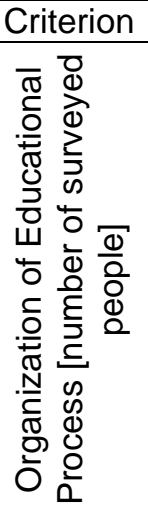 } & \multicolumn{2}{|c|}{ Indicators } \\
\hline & & & & 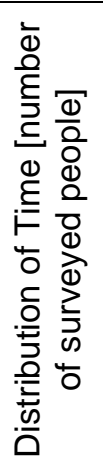 & 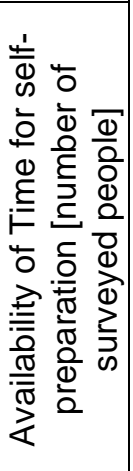 \\
\hline 2014 & 144 & $\begin{array}{l}\text { dissatisfied } \\
\text { satisfied }\end{array}$ & $\begin{array}{l}46 \\
98\end{array}$ & $\begin{array}{l}95 \\
49\end{array}$ & $\begin{array}{c}104 \\
40\end{array}$ \\
\hline 2015 & 196 & $\begin{array}{l}\text { dissatisfied } \\
\text { satisfied }\end{array}$ & $\begin{array}{c}111 \\
85\end{array}$ & $\begin{array}{c}122 \\
74\end{array}$ & $\begin{array}{c}148 \\
48\end{array}$ \\
\hline 2016 & 234 & $\begin{array}{l}\text { dissatisfied } \\
\text { satisfied }\end{array}$ & $\begin{array}{c}146 \\
88\end{array}$ & $\begin{array}{c}190 \\
44\end{array}$ & $\begin{array}{c}194 \\
40\end{array}$ \\
\hline 2017 & 284 & $\begin{array}{l}\text { dissatisfied } \\
\text { satisfied }\end{array}$ & $\begin{array}{c}56 \\
102\end{array}$ & $\begin{array}{c}221 \\
45\end{array}$ & $\begin{array}{c}223 \\
43\end{array}$ \\
\hline
\end{tabular}

A general regularity in the dynamics of the indicators of overall distribution of time in Vasil Levski National Military University and the availability of limit of time for preparation for the university subjects (selfpreparation) for the period 2008-2017 is the sharp increase of dissatisfaction in 2016 and 2017, respectively 81 and $84 \%$, and 83 and $84 \%$.

Certain satisfaction increase of the indicator for overall distribution of time is observed in 2011 and 2012, when satisfaction is greater than dissatisfaction. The greatest dissatisfaction according this indicator, the questioned people express by the overall distribution of time probably because they associate it with the completion of unspecific activities that are not included in it.

Diagnosing the availability of limit of time for preparation for the university subjects shows that average $69 \%$ of the questioned cadets for the period are dissatisfied with the lack of time for preparation for the university subjects. It is necessary to emphasize that the expressed dissatisfaction regarding the overall distribution of time has connection with the deprivation of or with not keeping the time for self-preparation to a high extent. This deprivation or not keeping has negative influence on motivation, and in "heavier" cases could lead to indifference and lack of motivation.

The results show that the main reason for dissatisfaction increase after the criteria "Organization of Educational Process" is most probably rooted in the introduction of new curricula in 2016 . The characteristics of these curricula $x-x x-16$ is that the military training increases by 600 training hours and respectively, the budget of studying time increases from 80 training days according the former curricula, to 90 training days according the new curricula. This leads to maximum burden of minimum 6 training hours within the training days, and because of number of subjective and objective factors, sometimes the training day embraces even 10 training hours (Terziev, Nichev, Bogdanov, 2017c).

\section{Ways of Training}

Training is organized and systematically conducted process of active interaction, where the teacher's leading activity stimulates and directs the training activity and the trainees' behaviour with a view to achieving certain goals. It is bilateral process - of teaching and acquiring knowledge, establishing skills and turning them into habits (Terziev, Nichev, Bogdanov, 2017c).

In the questionnaire studying the trainees' satisfaction regarding indicator „Way of Training” the included questions concern the training in military and civil specialization, the used training forms (lectures, exercises, seminars, practical studies, etc.), the used methods of training (oral, written, visual, practice, etc.), the 
accessibility and ease of mastering form of teaching, the relevance of the taught material to the novelties in the particular field, the practical purpose of knowledge, the conducted current control in the classes, the objectivity at evaluating the knowledge, the way the trainees are stimulated, the effectiveness of the conducted consultancies, the way of holding the semester exams, the usefulness of the acquired knowledge, the availability of educational literature, teachers' attitude towards the educational process, the erudition and professionalism of the teachers and the contacts cadet - teacher. The dynamics in the dissatisfaction of the studied persons from the All-Army Faculty on the criterion "Way of Training" for the period 2008-2017 is shown on Figure 4.

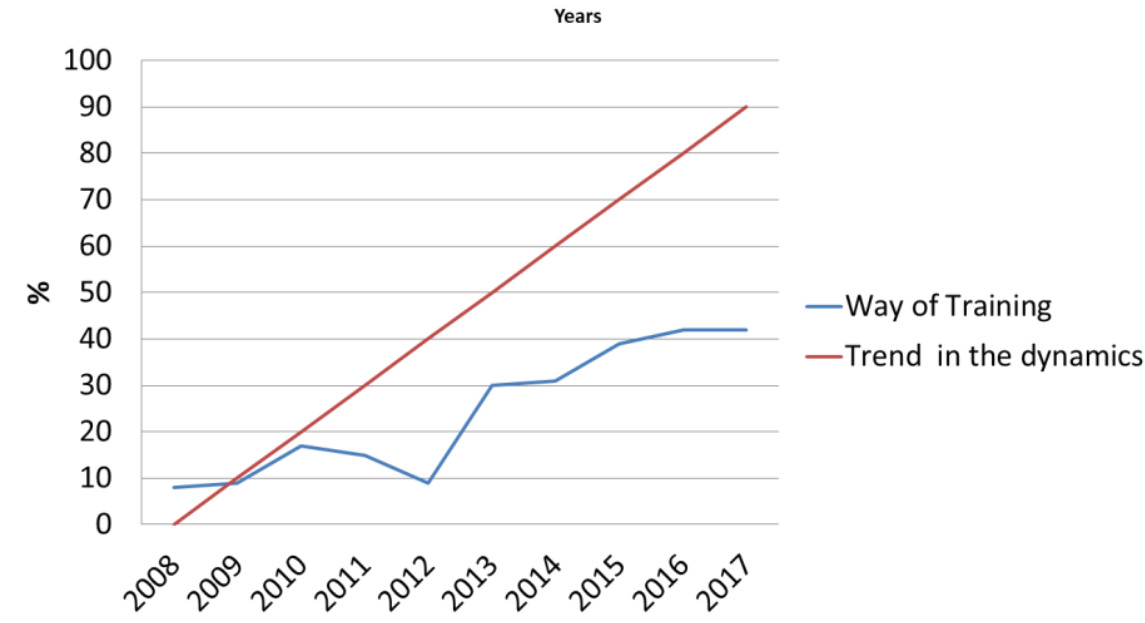

Figure 4. Dynamics in the dissatisfaction of the studied persons from the All-Army Faculty on the criterion "Way of Training" for the period 2008-2017.

The main trend in the dynamics after indicator „Way of Training” of the trained cadets in the All-Army Faculty is expressed in the low dissatisfaction in the period $2008-2012$ - from $8 \%$ to $17 \%$ and the sharp dissatisfaction escalation in the period 2012-2017 - from $9 \%$ to $42 \%$. During the studied period, the highest satisfaction for the indicators under the criterion "way of training" is for various criteria but among the lowest satisfaction is for the indicator "the way the trainees are stimulated". Figure 4 illustrates the dynamics of dissatisfaction of the studied people in the All-Army Faculty after the criterion "way of training" for indicator "the way the trainees are stimulated" for the period 2008-2017 and is shown on Figure 5.

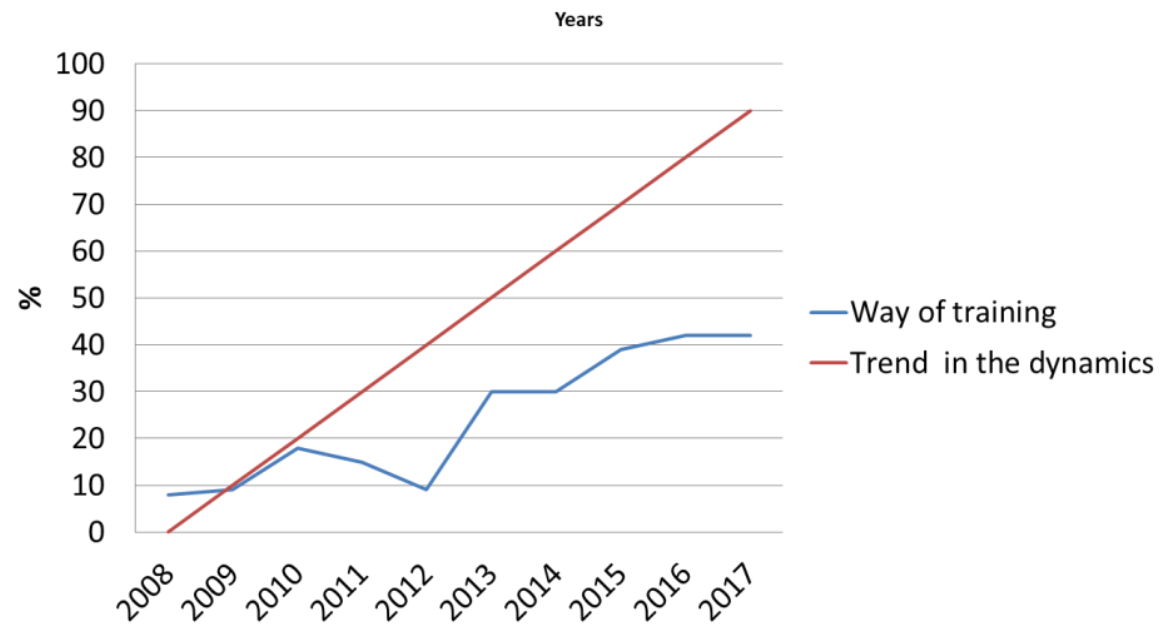

Figure 5. Dynamics of dissatisfaction of the studied people in the All-Army Faculty after the criterion "way of training" for indicator "way the trainees are stimulated" for the period 2008-2017.

The results evidence that the trainees' dissatisfaction holds the highest levels within the range from $39 \%$ to 42\% in 2015, 2016 and 2017 and this gives grounds for this period detailed analysis. Figure 6 illustrates the percentage correlation of the trainees' dissatisfaction under the criterion "Way of Training" and the relevant indicators. 


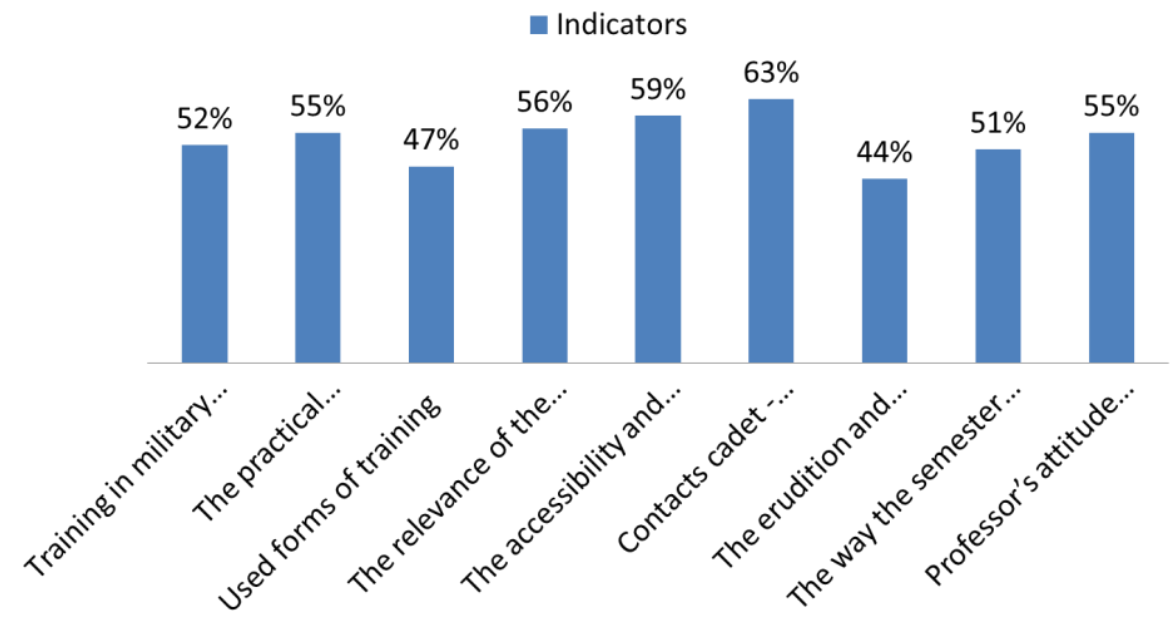

Figure 6. Percentage correlation of trainees' dissatisfaction after the relevant indicators for criterion "Way of Training" for the period 2016-2017.

According to the analysis's results, it can be established that significant part of questions from the ones set in the questionnaire are outside the competencies of the respondents cadets (the training in military and civil specialization, the used training forms - lectures, exercises, seminars, practical studies, etc., the used methods of training - oral, written, visual, practical, etc., the usefulness of the acquired knowledge). It is necessary to emphasize that the listed above issues are regulated in the regulatory framework for acquiring university degree in specialties from the regulated profession of "Officer for Tactic Level of Management" and the requirements of the cadres' users included in the qualification characteristics for the curricula.

The quality of life is the extent of welfare and personal satisfaction felt by the person after various criteria of physical, psychological and social nature. Satisfying individual's personal needs, the good status of health, physical comfort, good nutrition, physical activity, psychic health, social activeness are of quite significance for each personality.

The questionnaire for studying the trainees' satisfaction after the indicator "Quality of life” includes questions connected with the living conditions, internal order and organization, the relationship with the teachers, the relationship with commanders and chiefs, relationship with colleagues.

The dynamics of dissatisfaction of the studied people in the All-Army Faculty after the criterion "Quality of life" for the period 2008-2017 is shown on Figure 7.

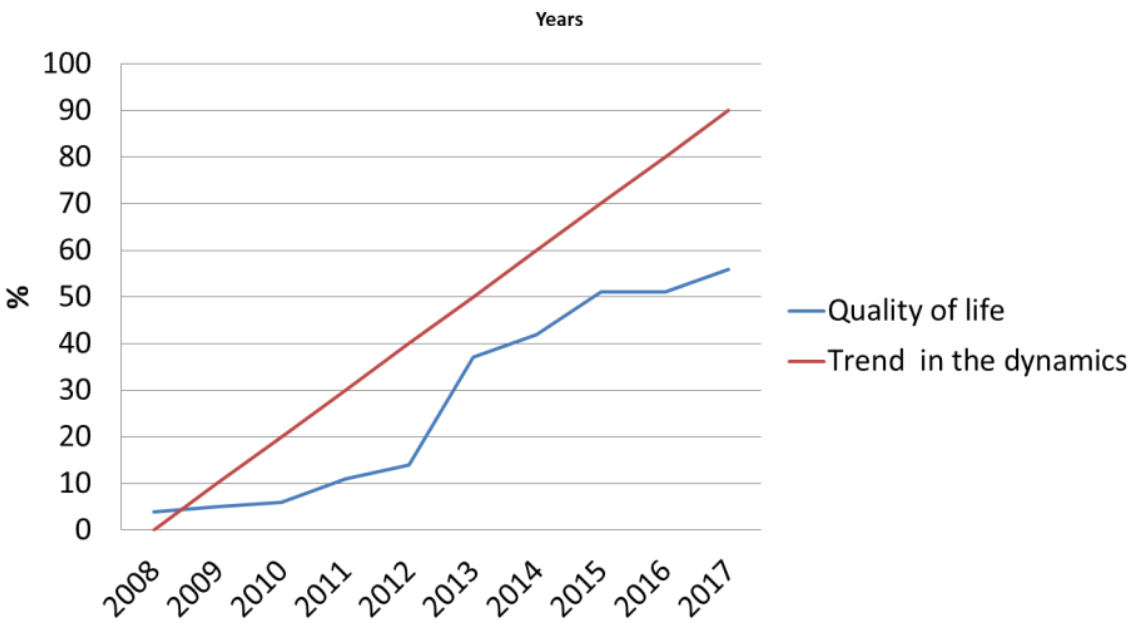

Figure 7. Dynamics of dissatisfaction of the studied people in the All-Army Faculty after the criterion "Quality of life" for the period 2008-2017.

The main trend in the dynamics after the indicator "Way of training" of the cadets trained in the All-Army Faculty is expressed by the low dissatisfaction during the sub-period $2008-2012$ - from $4 \%$ to $14 \%$ and the sharp escalation of dissatisfaction during the sub-period $2012-2017$ - from $14 \%$ to $56 \%$. During the reviewed period, the highest satisfaction after the indicators from the criterion „way of training" has various criteria, but 
also, one of the lowest satisfaction is after the indicators status of food regarding quantity and quality and the bad status of the study rooms and halls and especially the lack of heating during the winter period (Terziev, Nichev, 2017d; Terziev, Nichev, 2017e; Nichev, 2017f; Nichev, 2017g).

The results evidence that in 2015, 2016 and 2017 the trainees' dissatisfaction by the quality of life in Vasil Levski National Military University is stably over $50 \%$ and this gives grounds for detailed analysis of that period. Figure 8 illustrates the percentage correlation of cadets' dissatisfaction after the criterion "Quality of life" and the relevant indicators (Nichev, 2017h; Georgiev, 2019; Georgiev, 2019a).

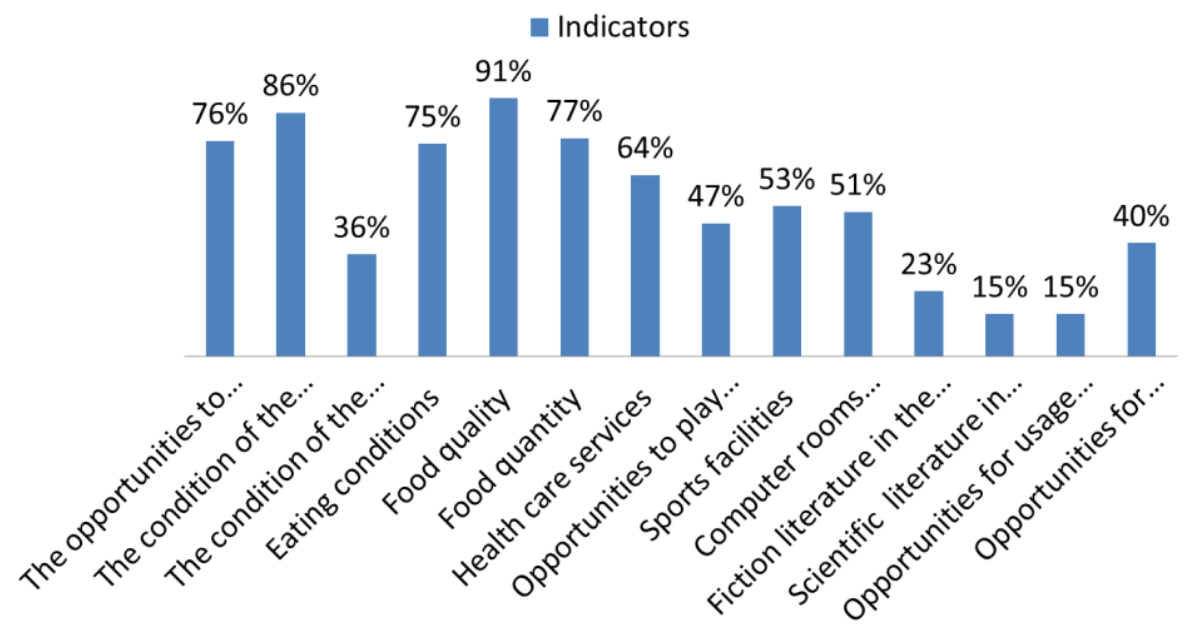

Figure 8. Percentage correlation of cadets' dissatisfaction after the relevant indicators from criterion „Quality of life" for the period 2015-2017.

At classes, the cadet's interest towards the military profession is formed through provoking positive emotional status with its gradual turning into stable psychic education and then trend to particular military specialty.

\section{CONCLUSION}

The psychologists from section "Military Psychology" processes the data and elaborate summarized report with the results from the questionnaire study for each category of trainees, and then present it to the Head of the university. On the grounds of the results' analysis, "Education and Accreditation Department" of the National Military University elaborates plan for improving the quality of educational process and way of living and submits it for adoption to the Academic Council (Glushkov, Simeonov, Georgiev, 2018; Glushkov, Simeonov, 2018a; Glushkov, Simeonov, 2018b).

The methods of evaluation of the quality of education and specialty maintenance defines the goal, criteria, indicators, order and the consequence of conduction of education and specialty maintenance quality evaluation. It aims collecting, summarizing and presenting information to the academic management of the university (faculty), the university (faculty) commission on quality for the activity improvement in all directions, by which to increase the quality of education and scientific work for achieving correspondence to the announced academic standards on the specialty. Adopted at meeting of the Academic council 2003, amended and supplemented at meeting № 11/29.05.200 of the Academic council and never applied (Angelov, 2015; Angelov, 2016-a)!

The methods of evaluating the quality of education and syllabus is developed as an element of the general evaluation (self-evaluation) of the quality management system in Vasil Levski National Military University and includes Syllabus Evaluation by basic criteria, their scope and contents, where the way of evaluation is indicated; Evaluation of the cadets' and students' preparation according to the users' opinion, which is formed on the grounds of a questionnaire with commanders, managers of companies and organizations, and chiefs at various levels during the trainees' probation period by indicators that form the criteria for the cadets and students; Evaluation of the teaching and mastering of the educational material - it is formed on the grounds of a questionnaire conducted among the trainees after indicators, grouped by the presented criteria, with separate training groups, classes or streams, not less than once a semester, after finishing certain topic, module or entire subject (Petrov, 2018c; Petrov, Georgiev, 2019b; Petrov, 2019c). 


\section{REFERENCE LIST}

Terziev, V., Nichev, N. (2017). Analysis of the environment for military educational system functioning and its impact on the preparation of cadets for military professional activities in the republic of Bulgaria. // Proceedings of SOCIOINT 2017- 4th International Conference on Education, Social Sciences and Humanities 10-12 July 2017- Dubai, UAE, 2017, ISBN: 978-605-82433-1-6, pp.627-630.

Terziev, Venelin. (2017a). Comparative analysis of the formation of military professional skills in the cadets to be trained in logistics specializations. // 6th International Conference On Education (IC-ED-2017), University of Zagreb Zagreb - Croatia 29 June 2017 - 01 July 2017, Abstracts Book, 2017, p.89.

Terziev, V., Banabakova, V., Georgiev, M. (2017b). Comparative analysis of the formation of military professional skills in the cadets to be trained in logistics specializations in Bulgaria. // 4th Central \& Eastern European LUMEN International Scientific Conference on Education, Sport and Health, 29-30 September 2017, Chisinau, Republic of Moldova, 2017, ISBN: 978-973-166-479-8, pp.256-258.

Terziev, V., Nichev. N., Bogdanov, P. (2017c). Comparative analysis of the formation of military professional skills in the cadets to be trained in logistics specializations. // Proceedings of ADVED 2017-3rd International Conference on Advances in Education and Social Sciences 9-11 October 2017- Istanbul, Turkey, 2017, ISBN: 978-605-82433-0-9, pp.671-677.

Terziev, V., Nichev, N. (2017d). Developing the readiness for the organizational activity of the cadets. // CBU International Conference Book of Abstracts March 22-24, 2017, Prague, Czech Republic, Innovations in Science and Education, 2017, ISBN 978-80-88042-09-9, p.164.

Terziev, V., Nichev, N. (2017e). Developing the readiness for the organizational activity of the cadets. // CBU International Conference Proceedings 2017, March 22-24, Prague, Czech Republic, Innovations in Science and Education, 2017, SSN 1805-997X (Print), ISBN 978-80-88042-07-5 (Print edition), pp.915-919.

Nichev, Nikolay. (2017f). Research on the preparation and professional realisation of newly appointed logistics officers. // International Conference Knowledge-Based organization, Vol. XXIII, No 1, 2017, pp. 399-404, DOI: 10.1515/kbo-2017-0066.

Nichev, Nikolay. (2017g). Evaluation of the Nutrition of the Bulgarian Army Military Personnel During the Preparation for Participation in Expeditionary Operations. Buletin Ştiinţific, Volumul XXII Nr. 2 (44), 2017, Publisher "Nicolae Bălcescu" Land Forces Academy, Sibiu, Romania, pages: 97-103, ISSN 2247-8396.

Nichev, Nikolay. (2017h). Social Security as Part of the National Security System of Bulgaria. Security and Defence, No 1(14), 2017, Publishing House of War Studies University, Warsaw, Poland, pp. 3-20, ISSN 2300-8741.

Georgiev, Marin. (2019). Improvement of the forming of the military professional qualities during the educational process. // 21 st International scientific conference: The teacher of the future, Budva, Montenegro, (07-09.06.2019), Institute of knowledge management - Skopje, Macedonia, 31, 2019, 6, pp. 1945-1950, ISSN 1857-923X (for e-version), ISSN 2545 - 4439 (for printed version).

Georgiev, Marin. (2019a). Balansirana karta za otsenka kato instrument za usavarshenstvane na upravlenieto. Akademiya za inovatsii i ustoychivost, Plovdiv, 2019, 147 str., ISBN 978-619-7246-24-7 (Георгиев, Марин. Балансирана карта за оценка като инструмент за усъвършенстване на управлението. Академия за иновации и устойчивост, Пловдив, 2019, 147 стр., ISBN 978-6197246-24-7).

Glushkov, P., Simeonov, S., Georgiev, M. (2018). Method of determination of the diurnal energy consumption of the cadets from the Vasil Levski National Military University. // ADVED 2018- 4th International Conference on Advances in Education and Social Sciences Abstracts \& Proceedings, 1517 October 2018- Istanbul, Turkey, International Organization Center of Academic Research, www.ocerints.org, Istanbul, Turkey, 2018, pp. 88-92, ISBN: 978-605-82433-4-7.

Glushkov, P., Simeonov, S. (2018a). Study of the daily energy requirement of the cadets from Vasil Levski National Military University. // ADVED 2018- 4th International Conference on Advances in Education and Social Sciences Abstracts \& Proceedings, 15-17 October 2018- Istanbul, Turkey, International Organization Center of Academic Research, www.ocerints.org, Istanbul, Turkey, 2018, pp. 67-76, ISBN: 978-605-82433-4-7.

Glushkov, P., Simeonov, S. (2018b). Historical analysis of the daily energy requirements of the cadets in the 
Republic of Bulgaria. // ADVED 2018- 4th International Conference on Advances in Education and Social Sciences Abstracts \& Proceedings, 15-17 October 2018- Istanbul, Turkey, International Organization Center of Academic Research, www.ocerints.org, Istanbul, Turkey, 2018, pp. 77-87, ISBN: 978-605-82433-4-7.

Angelov, Ivaylo. (2015). Aviatsionnoto obrazovanie v usloviyata na globalizatsiya. // Sbornik dokladi ot Godishnata universitetska nauchna konferentsiya na NVU „Vasil Levski” 2015, tom 10, s. 99-108, Izdatelski kompleks na NVU „Vasil Levski”, Veliko Tarnovo, 2015, ISSN 1314-1937 (Ангелов, Ивайло. Авиационното образование в условията на глобализация. // Сборник доклади от Годишната университетска научна конференция на НВУ „Васил Левски” 2015, том 10, с. 99-108, Издателски комплекс на НВУ „Васил Левски”, Велико Търново, 2015, ISSN 1314-1937).

Angelov, Ivaylo. (2016). Politika na evropeyskiya sayuz za razvitieto na aviatsiyata i aviatsionnoto obrazovanie. // Yubileyna nauchna konferentsiya 14 - 15 april 2016 g., Fakultet "Aviatsionen” NVU „V. Levski"- Dolna Mitropoliya, s.301-311, 2016, ISBN 978-954-713-109-5 (Ангелов, Ивайло. Политика на европейския съюз за развитието на авиацията и авиационното образование. // Юбилейна научна конференция 14 - 15 април 2016 г., Факултет “Авиационен” НВУ „В. Левски”- Долна Митрополия, с.301-311, 2016, ISBN 978-954-713-109-5).

Angelov, Ivaylo. (2016a). Vissheto aviatsionno obrazovanie $v$ drugi evropeyski darzhavi. // Sbornik ot dokladi na Yubileyna nauchna konferentsiya 14 - 15 april 2016 g., Fakultet” Aviatsionen” NVU „V. Levski”Dolna Mitropoliya, s.292-300, Elektronno izdanie, 2016, ISBN 978-954-713-109-5 (Ангелов, Ивайло. Висшето авиационно образование в други европейски държави. // Сборник от доклади на Юбилейна научна конференция 14 - 15 април 2016 г., Факултет” Авиационен” НВУ „В. Левски”Долна Митрополия, с.292-300, Електронно издание, 2016, ISBN 978-954-713-109-5).

Petrov, N. (2018c). Methopdology for asseing the quality of conducted training, Journal of Innovations and Sustainability, Vol. 4, No 3, 2018, p 27-37, ISSN 2367-8127 (CD-ROM), ISSN 2367-8151 (on-line).

Petrov, N., Georgiev, M. (2019b). Assessing of the military professional competencies. // Proceedings of SOCIOINT 2019- 6th International Conference on Education, Social Sciences and Humanities 24-26 June 2019- Istanbul, Turkey, International Organization Center of Academic Research, Istanbul, Turkey, 2019, pp. 462-472, ISBN: 978-605-82433-6-1.

Petrov, N, (2019c). Quality of conducted training system model. // Proceedings of SOCIOINT 2019- 6th International Conference on Education, Social Sciences and Humanities 24-26 June 2019- Istanbul, Turkey, International Organization Center of Academic Research, Istanbul, Turkey, 2019, pp. 473-482, ISBN: 978-605-82433-6-1. 